Kantian Review, 17, 2, 327-356 (C) Kantian Review, 2012

doi:IO.IOI7/SI3694I54I2000088

\title{
A Kantian Critique of the Care Tradition: Family Law and Systemic Justice
}

\author{
HELGA VARDEN
}

University of Illinois at Urbana-Champaign

\begin{abstract}
Liberal theories of justice have been rightly criticized for two things by care theorists. First, they have failed to deal with private care relations' inherent (inter)dependency, asymmetry and particularity. Second, they have been shown unable properly to address the asymmetry and dependency constitutive of care workers' and care-receivers' systemic conditions. I apply Kant's theory of right to show that current care theories unfortunately reproduce similar problems because they also argue on the assumption that good care requires only virtuous private individuals. Giving up this assumption enables us to solve the problems regarding both private care relations and systemic injustice.
\end{abstract}

Keywords: Kant's doctrine of right, private right, public right, care relations

\section{Introduction}

For the past three decades, what is now called the 'care tradition' has been central to identifying serious weaknesses in contemporary liberal theories' ability to critique private and systemic relations of care. The underlying problem is that liberal theories understand all moral relations as relations between autonomous and independent individuals whose interactions are governed by actual consent and universal laws. ${ }^{\mathrm{I}}$ Universal laws, in turn, are viewed as laws to which persons can be seen as hypothetically agreeing in virtue of being reasonable persons who respect each other's individual rights. The problem is that this liberal perspective can make good sense neither of private care relations nor of the systemic issues associated with the provision of care.

Care theorists contend that often liberal theories simply neglect private care relations altogether by implicitly or explicitly delegating them to

CAMBRIDGE JOURNALS

http://journals.cambridge.orgownloaded: 12 Oct 2012
VOLUME 17 - 2 KANTIAN REVIEW $\mid 327$

IP address: 140.192 .110 .226 
the so-called 'man's castle'. And even when liberal theories do engage these relations, care theorists convincingly argue that they fail adequately to deal with their inherent (inter)dependency, asymmetry and particularity. First, care theorists typically agree with Bernard Williams (1976) that liberal theories' commitment to impartiality makes them incapable of capturing the importance of particularity in moral relations. ${ }^{2}$ Second, the liberal perspective of the independent, autonomous person is seen as blinding liberals to care relations' asymmetry. Because physically or mentally impaired, sick or immature care-receivers do not choose to be dependent, their relations are fundamentally unequal. Care theorists therefore take themselves to expose what Annette Baier calls the liberal 'myth that moral obligations arise from freely chosen associations between ... equals' (Baier 1996: 29; original emphasis). ${ }^{3}$ Similarly, Virginia Held emphasizes that newborn children do not choose their parents on whom they are radically dependent to act on their behalf. Moreover, she continues, patients dependent upon their healthcare professionals, pupils dependent upon their teachers or clients dependent upon their attorneys, to assist in the setting and pursuing of ends are not in relations of equality. In each case, one person necessarily acts on behalf of or assists another in making private life choices (2006: 3I, 37-8, I33). Finally, some care relations are characterized by interdependence rather than dependence. For example, spouses are interdependent in that they share a private life or household (Baier I996: 29-30; Held 2006: 52-3). The particularity, asymmetry and (inter)dependency constitutive of private care relations make worrisome the belief that they can be understood through the liberal lens of autonomous, independent individuals.

Care theorists also argue that the liberal perspective of the autonomous, independent person's hypothetical or actual consent is inadequate to critique systemic care relations. Asymmetric care-receivers and care providers often do not have the necessary means to be on a par with those with whom they are interacting. Much of the world's care work is unpaid labour by women dependent upon husbands, or paid work by vulnerable servants, and many disabled and sick people do not have the resources to pay for the assistance they need. The ubiquity of this sort of asymmetry, care theorists maintain, should undermine our trust that principles of actual and hypothetical consent between autonomous, independent persons can ensure justice (Baier 1996: 28; Kittay I999: 53-4).

Care theorists therefore reject the notion that dominant liberal theories have sufficiently critiqued care relations. Yet although they have a shared aim to provide a very different perspective for their analysis, they do not,

328 KANTIAN REVIEW VOLUME 17 - 2

CMMBRIDGE JOURNALS 
however, agree on which perspective this is. Roughly, there are two types of care theories: those that propose that an account of care should be added to traditional liberal accounts of justice, and those that propose that a traditional liberal account can be modified so as to include an account of care. The first type maintains that a more complete ethical theory comprises both an account of care and a liberal account of justice. The challenge is how to reconcile justice and care. Some argue that the liberal assumption that justice is 'prior' to care, that justice is the most important value, is problematic. For example, Baier (I996: I9) argues that the care tradition challenges the 'priority of justice', or that 'justice is the "first" virtue of social institutions'. Rather, 'the best moral theory has to ... harmonize justice and care' (I996: 3 I-2; cf. Clement I996: 5, I I9). Indeed, in recent work, Held reprioritizes by placing care before justice, meaning that care provides the framework within which justice can and should exist. The second type, perhaps argued most prominently by Eva Kittay, maintains that care should be included as a constituent part of a modified liberal (in her case Rawlsian) theory of justice. ${ }^{4}$

I argue that, despite their important contributions, currently available care theories fail adequately to address and solve the very problems they have correctly identified in liberal theories. Indeed, they actually reproduce similar problems in their own accounts. The reason is that, like much liberal theory, the care tradition argues from two core assumptions: (I) that ideally good caring relations require only virtuous private individuals, and that consequently (2) the role of the state is merely to remedy some individuals' vices by protecting all individuals' rights against one another. As long as these two assumptions are guiding, we cannot generate the kinds of institutional structures necessary to ensure rightful care relations both privately and systemically. Somewhat surprisingly, perhaps, I argue that Kant's theory of justice can help both care and liberal theories solve their respective problems.

The paper is structured as follows. Section 2 argues that until we give up the assumption that good care requires only virtuous private individuals, we cannot take sufficiently seriously the problems associated with the particularity, asymmetry and (inter)dependency constitutive of private care relations. I first utilize Kant's account of private right to generate internal critiques of Held (2.I) and Kittay (2.2). In section 2.3, I then present Kant's alternative, which views an account of private care ('status') right and the establishment of the liberal state and its legal system of family and fiduciary law as constitutive of good caring relations. The conclusion, contra Held, is that there is a sense in which

CAMBRIDGE JOURNALS

http://journals.cambridge.orgownloaded: 12 Oct 2012
VOLUME 17 - 2 KANTIAN REVIEW $\mid 329$

IP address: 140.192.110.226 
rightful care is prior to virtuous care, and, contra Rawls and Kittay, that a liberal account of just private care relations must include relevant accounts of both private and public right. Section 3 turns to systemic justice by challenging the assumption by Held and Kittay that the state's function is merely to remedy some individuals' vices by protecting individuals' rights against one another. Section 4 offers a Kantian revision of Rawls that overcomes the problems identified in both care and prominent liberal theory. I conclude that Kant's theory of justice, although a central target of much criticism from care theorists, provides a way forward for liberal and care theory alike.

\section{Private Relations of Care: Held, Kittay, and Kant}

There is certainly intuitive appeal in the idea that good relations of care require only virtuous caring persons, and consequently that the public authority is fundamentally remedial in nature. Surely, the intuition says, public institutions are needed only when things have gone horribly wrong, and good caring relations exist prior to the establishment of the state. Therefore, the state's coercive institutions are legitimate only in response to the absence of proper care or in the presence of serious neglect and abusive violence. This intuition, however, results in conceptions of care (in both Held and Kittay) that replace the 'man's castle' with the 'caregiver's castle'.

\subsection{Care as Prior to Justice? A Kantian Critique of Held's Private Care Relations}

Justice, Held argues, is concerned with assurance of equality, fairness, freedom, voluntary autonomous choices, consistent application of abstract and universal laws - in short, the area of individuals' rights to freedom and equality. ${ }^{5}$ Care, in contrast, is seen as a practice made up not only of particularity, but also of relations of inequality, dependence and interdependence. ${ }^{6}$ Moreover, the practice of care concerns the work of caregiving; it is the sphere of 'social bonds and cooperation' constituted by 'relations between particular persons with their particular needs' (I4-I 5, 40). Held also emphasizes that the sphere of care limits the pursuit of self-interest on the part of caregivers $\left({ }_{13} 6\right)$, and is one in which 'persons respond ... with sensitivity to the needs of particular others with whom they share interests' $\left(6_{3}-4\right)$. Caregivers constituted in this way, she continues, have the appropriate emotions, as well as the right moral motivation, namely, the caring motivation (Iof, cf. Baier I995: 23-4, 3I). Virtuous caregivers perform caring activities because they care for their particular care-receivers. ${ }^{7}$

330 KANTIAN REVIEW VOLUME $17-2$ CAMBRIDGE JOURNALS 
Since both justice and care are seen as essential values for any moral theory, and since feminism has 'enabled us to see that these are different values', Held continues, a crucial challenge for care theory concerns how to 'mesh' or combine them in the right way $(68-72) .{ }^{8}$ Her suggestion is that we should consider care as providing the framework within which justice operates: care is prior to justice. One piece of evidence that care is causally and morally prior to justice is, Held says, that good caring relations can exist and actually have existed prior to justice, whereas justice cannot and never has existed prior to care. ${ }^{9}$ Because care is prior, Held argues that though the perspective of justice, and primarily law, enables useful abstractions for the analysis of certain areas of moral life, we should resist the 'imperialistic' expansion of legalism to cover all areas of life. ${ }^{10}$ Instead, justice should be applied within the wider framework set by the perspective of care, and justice should have priority only in the more limited moral sphere essentially constituted by individuals' rights and their assurance. In contrast, in the sphere of care, the sphere of 'children', 'family' and 'friends', 'priority should be given to expansive care, though the basic requirements of justice surely should also be met' $(\mathrm{I} 7)^{\mathrm{II}}$

Note, importantly, that Held does not believe that all justifiable uses of coercion should be analysed in terms of justice and rights. She emphasizes that caring persons will use coercion to deal with conflicts incurred in their care relations. ${ }^{\mathrm{I} 2}$ For example, parents, rather than courts of law, punish their children (24, 4I, I 5 I). Since care relations involve an application of coercion, it is of utmost importance that objective standards of care are developed for when conflicts arise. ${ }^{\mathrm{I}}$ Examples include standards of mutual respect and the empowerment of the dependent (56). To realize these standards in care relations, Held appeals to a revised version of hypothetical consent, one appropriate for non-autonomous care-receivers. Obtaining the right perspective on behalf of non-autonomous care-receivers requires imagining what we would agree to if we were children (77), or stated less provocatively, if we were morally incapacitated in the relevant sense. Held suggests, for example, that a suitable policy of justice is one according to which families must recognize that all their children have equal rights to nourishment, education and freedom ( $134-5)$. Nevertheless, the realization of these rights should be sought in a caring way, meaning that, if possible, they should be protected without destroying the caring relations of the family. For example, she argues, if the father fails to respect his child's rights, then the child rightly refuses to accept the father's behaviour. But, if possible, the child should work within the

CAMBRIDGE JOURNALS

http://journals.cambridge.orgownloaded: 12 Oct 2012
VOLUME 17 - 2 KANTIAN REVIEW $\mid \mathbf{3 3 1}$

IP address: 140.192.110.226 
family relation to restore proper behaviour on the part of the father. Of course, in cases of a severe violation of rights, such as serious abuse, the abused is correct in refusing the relationship altogether. In less dramatic scenarios, he is right to refuse the relationship as it stands, but should stay and work on the relationship from within (ibid.).

Why, then, does this conception lead to the caregiver's castle? To set the stage for Kant's approach to these relations in section 2.3, I will here focus only on the aspects of Held's position that I believe Kantians will find particularly problematic because they lead to the caregiver's castle. ${ }^{I 4}$ To start, I believe Kantians' first objection to Held's analysis is that it presupposes that the non-autonomous care-receivers are capable of the moral autonomy of which they by definition are incapable. Take the example above. The children are seen as recognizing rights and having duties to resolve conflicts in a 'caring way'. But presumably, as children, they are incapable of such moral responsibilities. The point here is not to deny that children become increasingly capable of assuming responsibility for themselves, but that an account of care relations must include an account of the normative care relation insofar as it involves persons incapable of moral responsibility. Held may respond that she does not mean that children should actually recognize their rights and obligations. Rather, she is after a determination of the objective standards of care that adults external to the relation should use when they evaluate these relations. She wants to identify how another must reason when establishing whether or not intervening in a particular parent-child relation is justified. But even so, I believe Kantians will argue, this response can at most explain how the derivative relation between the intervener and the original people in the relationship is rightful. It does not explain how the original relationship between the child and the parent can be made rightful. Moreover, it is also not clear that such a solution takes the particularity of the care relation sufficiently seriously. Introducing a stranger into the particular (original) relation seems inconsistent with respecting its integrity. The problem is that if particular parents and their children are the ones sharing lives, strangers cannot unilaterally decide to impose themselves on such a relationship (in which they are not parties) without thereby doing something objectionable to the children and without thereby losing the particularity of the relation. As emphasized by the care tradition and Held in their objections to prominent liberal theories, the self is constituted by particular care relations. But external third parties are not a part of the original relational whole. So why should the children simply be seen as welcoming the strangers who now demand to have such a

332 KANTIAN REVIEW VOLUME 17 - 2

CMMBRIDGE JOURNALS 
particular, private care relationship with them? Naturally, such intervention might be the only way to stop some parents from destroying their children, but it is far from clear that it is the ideal solution. ${ }^{15}$

A second, likely objection from Kantians, again for reasons that will become clearer below (section 2.3), is as follows: if care is prior to and independent of justice and caregiving involves coercion, then some coercive aspects of care relations wrongly end up beyond the scope of justice. Consequently, the coercive sphere of care, by definition, is ruled by the stronger, who typically, but not always, is the caregiver. Since there are neither legal rights nor legal protections in this sphere the dependency, asymmetry, and particularity constitutive of care relations are in principle untouchable by law. In addition, a right to intervention by outsiders also appears to require that justice is constitutive of the coercive sphere of care. But then care would not be prior to or independent of justice. Thus, in having care independent of and prior to justice Held has reproduced the very problem she associates with liberal theories: the coercive aspects of care relations are relegated to a 'castle', but this time, to the 'caregiver's castle'.

A final objection from the Kantians is that the problem of might ruling care relations arises also in the articulation of ideal care relations. Held assumes that good caring relations require only private individuals who virtuously apply the objective principles of care and, presumably, the objective principles of justice enabling everyone's rights, including children's rights. (Let us assume we know these objective principles of care and justice.) This implies that virtuous caregivers have sole authority to apply the objective standards of care and of justice, since care-receivers by definition cannot do so. Virtuous caregivers are authorized unilaterally to set particular ends on behalf of care-receivers incapable of identifying and setting their own ends. For example, virtuous parents are correct in viewing themselves as in principle the only ones with standing to determine which particular ends their child should pursue. But then particularity, dependency and asymmetry constitutive of care relations result in the subjection of the care-receiver's private life to the caregiver's choices. The problem is that the ideal application of a principle would consist in analysing the care-receiver's private life simply through the lens of the caregiver's private choices. Therefore, Held hasn't succeeded in showing how private particular, asymmetrical, dependency relations give proper voice to both interacting parties. The resulting care relations on Held's account are consequently still normatively problematic. In holding care independent

CAMBRIDGE JOURNALS

http://journals.cambridge.orgownloaded: 12 Oct 2012
VOLUME 17 - 2 KANTIAN REVIEW $\mid 333$

IP address: 140.192.110.226 
of and prior to justice, Held reproduces versions of the very problems she identifies in liberal theory and is trying to solve. Care-receivers are still living in the caregiver's castle. ${ }^{16}$

\subsection{A Kantian Critique of Kittay's Account of Just Private Care Relations}

Instead of presenting care as prior to and independent of justice (and hence being subject to the problems therein), $\mathrm{Kittay}^{\mathrm{I}}{ }^{\mathrm{argues}}$ that liberal theories of justice should incorporate an account of care (IO2, IO8). Kittay begins with the observation that Rawls's hypothetical perspective of autonomous, independent persons 'effectively excludes as equal citizens two classes of persons whom Rawls did not intend to exclude: those who are dependent upon others, and those who attend to their needs' (78). To compensate, she proposes several amendments to Rawls's account. First, the 'Humean circumstances of justice', namely moderate scarcity and limited benevolence, are expanded to include the inconveniences related to concerns of care and dependency (IO8). Second, she adds to the two Rawlsian moral capacities (a conception of justice and a conception of the good) a natural capacity for a conception of care. Third, to Rawls's list of primary goods is added the right to receive care (IOI-2). Consequently, those in the original position (arguing behind the veil of ignorance) do not know whether they are autonomous or non-autonomous, or whether they are independent or dependent persons. Thus, they are seen as likely to adopt a third principle of justice as fairness, '[t] he principle of the social responsibility for care':

To each according to his or her need for care, from each according to his or her capacity for care, and such support from social institutions as to make available resources and opportunities to those providing care, so that all will be adequately attended in relations that are sustaining. ( I I3; original emphasis deleted)

By incorporating the needs of both caregivers and care-receivers into the 'basic structure' of the state, Rawls's theory is now seen as responsive to the specific challenges involved in envisioning just care relations. The state ensures that those in need of care receive it and that caregivers are provided with sufficient material support to provide it (89-90).

An application of Kant's account of justice to Kittay's and Rawls's positions reveals the following problem also shared by Held: the assumption of the Humean circumstances of justice (in A Theory of

334 KANTIAN REVIEW VOLUME 17 - 2




Justice and in Kittay 1999), which entails the assumption that good care ideally requires only virtuous private individuals $(34-5)$, precludes a solution to the specific problems of asymmetry, particularity and (inter)dependency inherent in private care relations. And (like Held) neither Kittay nor Rawls notes this consequence. Instead, they proceed directly to an analysis of the nature of the public political, social and economic institutional framework ('the basic structure') that is supposed to provide for just relations, including care relations. In so doing, both Kittay and Rawls assume that an account of public right (rights citizens have against public institutions) is sufficient for private right (rights private individuals have against one another). But, as we will see below, for Kant, capturing the particularity, asymmetry and (inter)dependency involved in private care relations requires that ideal private right and public right perspectives are distinguished. This is, I believe, why Kant includes a separate account of private right, which includes property, contract, and especially important for care relations, family or what he calls 'status' rights. Status rights concern rights holding between spouses, between families and their servants and between parents and their children.

If we apply Kant's position to the Kittay-Rawlsian position, the first objection, then, is that neither Rawls nor Kittay provides a sufficient account of family rights. From the point of view of justice, Rawls (200I: I62) says that the reason for a right to have a family is simply 'to establish the orderly production and reproduction of society and of its culture from one generation to the next'. Moreover, Rawls's (200I: I63, I63, n. 42) only comment on same-sex marriage is that it seems a prima facie right that if some citizens have the right to marry, then all citizens should have such a right. And Rawls says nothing at all about the rights of servants. Similarly, Kittay explains neither why having a right to a family and to marry is important - for either straight or gay couples - nor what makes these rights different from other kinds of rights.

A second objection issuing when we apply Kant's account of status right to the theories of Kittay and Rawls is that, although Rawls (I996: 22 I, n. 8) clearly seems to claim that the state will protect children's rights against their parents, he gives no separate account of what those rights are or what is special about them. Instead, Rawls asserts that children's rights are protected through public right because they are future citizens: 'the principles of justice impose constraints on the family on behalf of children who as society's future citizens have basic rights as such' (200I: 598). But even if we accept the argument that the state can

CAMBRIDGE JOURNALS

http://journals.cambridge.orgownloaded: 12 Oct 2012
VOLUME 17 - 2 KANTIAN REVIEW $\mid 335$

IP address: 140.192.110.226 
enforce children's rights because children in the future will be able to exercise the two moral powers constitutive of citizenship, the account struggles to explain the rights of persons whose impairments are so severe as to preclude them from ever exercising these powers. Kittay avoids Rawls's appeal to future citizenship by including the third principle of care in the principles of justice. Nevertheless, the new principle of care is a principle of public right - claims dependent citizens have on public institutions to be provided with sufficient resources. But surely a child's claims in relation to its parents, for example, are different from the child's claims on public institutions. Indeed, public right cannot capture the asymmetry, (inter)dependency and particularity constitutive of private care relations - specific relations between particular individuals. Therefore, Kant's main proposal to Rawls, Kittay and Held, in my view, is that justice demands an account of private care rights different from public right. To see how Kant makes these kinds of argument in the Doctrine of Right, I now turn to his account of private care, or 'status', right (section 2.3) before turning to his account of systemic or public right in the final sections (section 3 and 4 ).

\subsection{A Kantian Account of Private Care ('Status') Right}

Kant calls private care relations 'status relations', of which there are three kinds: those between parents and their children, between spouses and between families and their servants. Kant acknowledges the need for this additional category of rights (in addition to private property and contract right): 'it is evident that ... there must necessarily be added to the headings of rights to things [property right] and rights against persons [contract right] the heading rights to persons akin to rights to things [status right]; the division made up till now has not been complete' $\left(M M\right.$ 6: $\left.282^{18}\right)$. We have seen already a number of reasons why this new category of right is significant. But how does Kant present his justification for the addition of 'status right'?

According to Kant, at the heart of status relations is a unified or shared private life or household within which one person can have authorization or standing over another. As such, status rights are not seen as against one another as independent persons, but rights to one another as (inter)dependent persons. Importantly, for our purpose, persons in private care relations have a right not to be abandoned by each other and a right and duty to care for each other when needed, including by acting on each other's behalf. For Kant, the core philosophical challenge is how to conceive of such standing in unified or shared private lives

336 KANTIAN REVIEW VOLUME 17 - 2

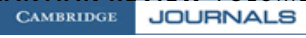


between equals, as well as between equals and unequals, in a way reconcilable with what he calls everyone's 'innate right to freedom'. Everyone is born with a right to freedom, which is a right to 'independence from being constrained by another's choice', insofar as one's exercise of freedom 'can coexist with the freedom of every other in accordance with a universal law' (MM 6: 237). Rather than a condition of slavery or serfdom in which one person's freedom is subject to another's arbitrary choices, interacting persons' actions must be reciprocally constrained by universal law. The difficulty (and why Kant sees the need for a new category) is how to conceive of care relations as governed by universal law rather than by some (the stronger) person's arbitrary choice. How can we make sense of rightful interactions in which dependent and interdependent persons have coercive rights in relation to a unified or shared private life or household? In short, Kant argues that because each type of care relation involves coercive authority within private lives, ordinary contracts and private property law are insufficient to make them rightful. Also necessary is protection by the public institution of family and fiduciary law. To speak as contemporary care theorists would, contract and private property law are incapable of dealing with the particularity, asymmetry and (inter)dependency of shared or unified private lives. Therefore, in addition to 'On Property Right' (MM 6:260-70) and 'On Contract Right' (MM 6: 27I-6), Kant includes a section 'On Rights to Persons Akin to Rights to Things' (MM 6: 276-84) - and all of these sections support his general conclusion of the entire private right discussion, namely that public legal institutions are necessary for rightful interaction.

Kant begins the section 'On Rights to Persons Akin to Rights to Things' by stating,

This right is that of possession of an external object as a thing and use of it as a person. - What is mine or yours in terms of this right is what is mine or yours domestically, and the relation of persons in the domestic condition is that of a community of free beings who form a society of members of a whole called a household (of persons standing in community with one another) by their affecting one another in accordance with the principle of outer freedom (causality). - Acquisition of this status, and within it, therefore takes place neither by a deed on one's initiative (facto) nor by a contract (pacto) alone but by law (lege); for, since this kind of right is neither a right to a thing nor merely a right against a person but also possession of

CAMBRIDGE JOURNALS

http://journals.cambridge.orgownloaded: 12 Oct 2012
VOLUME 17 - 2 KANTIAN REVIEW 337

IP address: 140.192.110.226 
a person, it must be a right lying beyond any rights to things and any rights against persons. (MM 6:276)

Household rights, then, involve rights to persons 'akin to rights to things' in that they involve the right to share a private household. A point of some confusion in the scholarship concerns Kant's claim that this right includes the right not to be abandoned by others. ${ }^{19}$ Some of this confusion is probably a result of the dramatic way in which Kant makes this argument. For example, for the right to non-abandonment in marriage Kant says, 'if one of the partners in a marriage has left or given itself into someone else's possession, the other partner is justified, always and without question, in bringing its partner back under its control, just as it is justified in retrieving a thing' (MM 6: 278). Similarly, regarding children, he says that parents are 'justified in taking control of them and impounding them as things (like domestic animals that have gone astray)' (MM 6:282). Finally, for heads of households and servants, the former has a right to 'bring [servants] back in his control by his unilateral choice', and 'fetch his servants back and demand them from anyone in possession of them, as what is externally his, even before the reasons that may have led them to run away and their rights have been investigated' (MM 6: 283). Although Kant here lets the language of who fetches whom reflect the stronger party's position (equals and unequals), one should not conclude that the weaker parties (servants and children) have no claims on the family. Kant devotes much time to children's rights 'to the care of their parents until they are able to look after themselves' (MM 6: 280), and servant contracts are either for a specified time or 'an unspecified time, within which one party may give the other notice' (MM 6: 283). Moreover, and crucially, even though no one has the right to abandon others, notice that the passage above emphasizes that these relations are made rightful only by being regulated 'by law' (MM 6: 276). So, in addition to being regulated by the principles of private status right rightful care relations require the public institution of family and fiduciary law. ${ }^{20}$ Hence, even though heads of households have the right to fetch their servants back prior to establishing the facts of the case, once back the servants' rights must then be investigated. The only authority with rightful standing to investigate these (or anyone's) private rights is the public authority, since only a public authority can institute the rule of law (lege). Hence even if one is right in fetching someone back, private use of coercion is at most 'provisionally' rightful - not 'conclusively' rightful, Kant says. To choose to interact in such a way (in accordance only with what is provisionally rightful) is consequently to do 'wrong in the highest degree',

338 KANTIAN REVIEW VOLUME $17-2$

CMMBRIDGE JOURNALS 
because it involves refusing to interact in rightful ways (MM 6: 307-8). The reason is that, for Kant, only a public authority rightfully exercises coercion; private uses of coercion, even if the result of conscientious and good application of the principles of private right (provisionally rightful), is not fully rightful (conclusively rightful).

2.3.1 Dependency relations: familial and fiduciary. There is a significant difference in the status relations between spouses, families and servants, and parents and children in that children cannot be morally responsible. Therefore, their actual consent cannot do the same justificatory work it does for morally responsible persons who join private households. Indeed, children do not consent to be in a relation with their parents in the first place, since their existence is merely the result of the parents' unilateral choice. By procreating, Kant argues, parents have 'brought a person into the world without his consent and on [their] own initiative, for which deed the parents incur an obligation' to take care of the person until it can take care of itself (MM 6: 28I). Parents have a right to

manage and develop the child, as long as he has not yet mastered the use of his members or of his understanding: the right not only to feed and care for him but to educate him, to develop him both pragmatically, so that in the future he can look after himself and make his way in life, and morally, since otherwise the fault for having neglected him would fall on the parents. They have the right to do all this until the time of his emancipation ... when they renounce their parental right to direct him as well as any claim to be compensated for their support and pains up till now. After they have completed his education, the only obligation (to his parents) with which they can charge him is a mere duty of virtue, namely the duty of gratitude. (MM 6: 28I)

Also important for Kant is that the parents' duty (in principle enforceable) to take care that their children develop their pragmatic and moral skills does not also issue an enforceable duty on behalf of the children to compensate the parents, or to take care of the parents as they grow old. Instead, the duty of gratitude is a duty of virtue for Kant; being grateful is something children ought to be when they have been treated well by their parents, but not something they can be forced to be. Once children have reached the age of emancipation they have the right to set and pursue their own ends, and though they would act immorally if they did not set the parents' well-being as an end, they do no wrong from the point of view of justice.

CAMBridge JOURNALS

http://journals.cambridge.orgownloaded: 12 Oct 2012
VOLUME 17 - 2 KANTIAN REVIEW $\mid 339$

IP address: 140.192.110.226 
Kant's analysis of the parent-child relation provides a suitable structure for fiduciary relations involving care-receivers who are unable to assume responsibility for (some aspect of) their own private lives. The similarity is that the beneficiary is dependent on the caregiver to set ends for her. Although consent is important in fiduciary relations generally, if one cannot assume responsibility for the particular issues at hand, one cannot meaningfully consent with respect to those issues. The problem inherent in status relations, where one person's private life is subject to the choices of another, is how to make them rightful without consent doing the justificatory work. It seems that the relation is tantamount to the children (or morally incompetent care-receivers) being involuntarily subjected to the choices of their parents (or caregivers). But this is simply to be enslaved. Similarly, if fiduciary contracts, say those between patients and physicians, were considered normal contracts, they would constitute slave contracts, for they would involve legally transferring one aspect of one's life (one's freedom) to the coercive authority of another private person's private choices. In both cases (involuntary and voluntary), the relation would be one in which one person's private life - one person's freedom - is made subject to another person's arbitrary choice. Such subjection is what characterizes slave relations, which is exactly what Kant's liberal ideal opposes. Commitment to the liberal idea of freedom involves approval only of interactions compatible with each person's right to freedom - namely the right to independence from having one's freedom subject to another's private, arbitrary choices and the right instead to have all one's interactions subject only to universal laws of freedom. How, then, are status relations (whether consensual or non-consensual) made rightful?

The subjection of one person's private life to the choices of another is made rightful, Kant argues, only through the establishment of a public legal authority with standing in the relationship (the liberal state's legal institution of family and fiduciary law). We see this in Kant's opening statement in the discussion of domestic right, that household right requires the establishment of law (lege). We see it also in his conclusion to the discussion of private right (private property, contract and household (status) right): 'From private right in the state of nature there proceeds the postulate of public right: when you cannot avoid living side by side with all others, you ought to leave the state of nature and proceed with them into a rightful condition' (MM 6: 307). Kant argues similarly when he starts his explication of the rightful condition in the Public Right section of the Doctrine of Right. There he argues that the fundamental reason why we need law to enable rightful relations,

340 KANTIAN REVIEW VOLUME 17 - 2

CAMBRIDGE JOURNALS 
including fiduciary law, is not because of our typical tendencies to act viciously but because it is the only way in which we can interact consistent with each other's right to freedom, that is, our right not to find our interactions subjected to each other's arbitrary, private choices ('what seems right and good' to us), but instead to universal laws of freedom (MM 6: 3II-I2). The state provides the ideal solution to ensuring rightful interaction when one party is authorized to act as the trustee of another. The establishment of public, legal institutions that specify, apply and enforce family and fiduciary law, therefore, is constitutive of rightful private relations. These institutions make it possible for care-receivers not to be subjected merely to caregivers' arbitrary, private judgements about what is in their best interest. Instead, a legal authority representing both parties and only both parties regulates the relation through the public institutions of family and fiduciary law. Therefore, the establishment of a public authority with standing in private care relations is the solution to the inherent asymmetrical dependence in care relations, without also sacrificing due respect for their particularity.

The establishment of the state as a legal authority over private care relations involves the public positing, application and enforcement of family and fiduciary law (private right) and backing up such laws with criminal law (public right). First, the state posits private law ${ }^{2 I}$ governing family and fiduciary relations (or relations involving some notion, broadly understood, of legal guardianship). These laws specify the general legal duties and rights parents and professionals have in relation to their beneficiaries. For example, the law can require specific standards of medical care, or specific provisions for achieving a particular educational level, and so on. Second, the state applies family and fiduciary law in disputed cases by the courts, but in most cases by legally entrusting individuals to do the day-to-day application. For example, parents are authorized to act as legal guardians of their children, and professionals - through the legal institution of licensure act as legal trustees for their beneficiaries. Thus, both parents and professionals are public, legal guardians or trustees who act on behalf of their care-receivers within the parameters set by family and fiduciary laws. Because parents and professionals are legal guardians or trustees, they are not permitted simply to abandon their beneficiaries. Moreover, because different caregivers (parents or professionals) are given legal standing within an individual beneficiary's life, they can challenge each other's judgements: they are legally obligated to report serious failings of care, and they are legally required to resort to public courts

CAMBRIDGE JOURNALS

http://journals.cambridge.orgownloaded: 12 Oct 2012
VOLUME 17 - 2 KANTIAN REVIEW $\mid \mathbf{3 4 1}$

IP address: 140.192.110.226 
when conflicts prove otherwise insoluble. Finally, the state posits criminal law (public law) to regulate those who intentionally break or through serious negligence fail to follow the requirements of family or fiduciary law.

Once the legal framework is constitutive of rightful caring relations, caregivers who fail to live up to their legal responsibilities are subject to the strictures of family or fiduciary law (private right) and criminal law (public right), and they can lose their standing as legal guardians or trustees (public right). Moreover, the state's legal institutions provide a framework within which virtuous caring relations can flourish, which is why we also have ethical duties to support the public institutional structure of care relations. Hence, the Kantian account here proposed agrees with Held that virtuous caring involves doing what is right from the right moral motivation. That is, we ought to want to ensure rightful care relations and we ought to do what is right because it is right. But it challenges Held's claim that care is prior to justice. Instead, the proposal is that that, ideally speaking, virtuous private care functions within liberal legal institutions, which is to say that there is a sense in which rightful care is prior to virtuous care. Kant's view also challenges Kittay's and Rawls's shared assumption that all we need in order to analyse rightful care relations is an account of citizens' claims on their public institutions. The legal institutions of both private and public right are required to dismantle the caregiver's mighty castle and replace it with justice, thereby providing the conditions under which truly virtuous interactions can occur. I return to further issues of public right or systemic justice - after first dealing with the private right categories of families and their servants and marriage.

2.3.2 Interdependency relations $I$ : families and their servants. The second type of 'status' or care relations Kant considers is between families and their servants, which are consensual care relations between unequals. These relations should not be analysed simply through the lens of actual consent and ordinary contract law, he argues, because of the personal (particular), asymmetrical and dependent nature of the relation of servants to the persons who employ them. Kant's main claim is that no one can be seen as being under an enforceable obligation to obey such contracts unless two conditions are met: such contracts must provide a mutual guarantee of non-abandonment, and a public authority must specify the general terms of interaction and have the standing to settle related disagreements concerning the application of these general rules.

342 KANTIAN REVIEW VOLUME 17 - 2

CAMBRIDGE JOURNALS 
The personal nature of these rights results from the important ways in which servants and the households in which they serve have unified their private lives. Servants contract to become a part of another's household, and the family accepts the legal obligation to consider them so. Thus, servants and families not only have rights against one another as they would have in normal contracts, but also rights to one another, since the two parties' private lives are interdependent. The servant needs the job to have a home, whereas the family needs the servant's personal assistance to function. These relations are also fundamentally asymmetrical. First, though the two parties are mutually dependent, they are not equally dependent, since the servant is poor and so fundamentally vulnerable to the decisions of the family. Second, though both parties must have a say with regard to the nature of their relations, they do not have an equal say for the family must have greater status in decisions about its own daily functions. For example, a servant charged with assisting a physically challenged child cannot disregard the parents' decisions with regard to their child. Servants are acting on behalf of a family within the family's household - they are not to determine the kind of household it ought to be.

Given the dependency and asymmetry of this type of care work, what assures the servant sufficient voice in the relation? What are the limits of the family's discretionary power? For example, exactly how much space, how much time off and what kind of health insurance should the servant have a right to? And which kinds of things cannot be asked of her, even if she de facto agrees? If the family had an, in principle, unchecked or unbounded right arbitrarily to specify the conditions under which the servant functions, the result would be a serf contract, which is inconsistent with the servant's innate right to freedom (MM 6: 283). Regardless of the family's dependence and whether the servant contributes to specifying the general terms and application of the contract, she remains more vulnerable due to the asymmetry of power in the relation.

Although Kant is brief, his solution to the problems raised by also this type of care relation is the establishment of a public legal authority to regulate and have standing in the domestic relation as constitutive of its rightfulness. Only by being regulated by law (lege) are these domestic relations made reciprocally respectful. Therefore, virtuous individuals as such cannot make such relations rightful. This is another reason why rightful care, in important ways, is prior to virtuous care. That millions of servants presently live under oppressive conditions is not due merely to a lack of virtue on the part of their employers, but to the failure of

CAMBRIDGE JOURNALS

http://journals.cambridge.orgownloaded: 12 Oct 2012
VOLUME 17 - 2 KANTIAN REVIEW $\mid \mathbf{3 4 3}$

IP address: 140.192.110.226 
states to institute proper legal institutions that specifically address problems issuing from the interdependency, particularity and asymmetry constitutive of these relations. ${ }^{22}$

2.3.3 Interdependency relations II: marriage. The final category of care rights concerns marriage, which - whether between straight or gay couples - is particularly important on the $\operatorname{Kantian}^{23}$ legal-political account. It is the means through which two persons can consensually unify their private lives as equals. Through marriage, spouses establish a shared private home in which they set ends together as well as on each other's behalf with their shared means. The marriage contract establishes an 'us', meaning the unification of two persons' private lives into one shared life that is subject to the choices of both, as equals. From the point of view of right, individual ends pursued by one of the spouses become, in important ways, common ends for both. Moreover, marriage is the only way in which one person can obtain a comprehensive right to another person - a right not to be abandoned, a right to sexual fidelity and a right to have a say with regard to how the other sets ends. As in the cases of fiduciary and servant relations, consent to such kinds of arrangements under a normal contract would be consent to slavery or serfdom, since one person would have an enforceable, unilateral right to set ends with regard to another person's private life. Hence, marriage contracts are unlike other contracts.

The Kantian account does not consider the marriage contract as giving rise to conclusively rightful coercion in the state of nature; only the public institution of marriage (and its body of specified law) can do so. Unilateral enforcement of the general principles of private right remains, we saw above, 'wrong in the highest degree' since it is irreconcilable with the innate right to freedom. For example, my wife may not mind if I unilaterally decide to buy a refrigerator for my office, or to spend $\$ 200$ on a haircut, but she might disagree with my choice if I unilaterally decide to buy a Ferrari, or to spend $\$ 20,000$ on gambling. The point is that within the state of nature there is no way to settle such (even reasonable) disagreements except by unjustifiable coercion - by one of us arbitrarily imposing her choices upon the other. The solution, again, is to establish the public institution of marriage law as part of family law to set limits within which individual choices regarding a shared private life take place, including laws governing which decisions any one spouse can make without the consent of the other. For example, the law typically requires both spouses' signatures upon the selling of their common home, or upon incurring a large debt (including by specifying what constitutes a 'large' debt). And, of course, to use

344 KANTIAN REVIEW VOLUME 17 - 2

CAMBRIDGE JOURNALS 
Kant's example, it has the right to determine whether one spouse has rightful claim on the other that he doesn't abandon him, to 'fetch the other back'. More generally, marriage laws also regulate the dissolution of marriages - again the only way to provide rightfully enforceable solutions to reasonable disagreements concerning the new distinctions between 'mine and thine'. How much, for example, should it count that my spouse supported me through law school, or bore the bulk of the responsibility of raising our children? Thus, the state's positing, application and enforcement of marriage law is constitutive of rightful private marriage relations and dissolutions. Also entailed is that the denial of the marriage right to same-sex couples is the denial of the possibility of rightfully unifying their private lives. Instead, same-sex couples are forced to remain in a condition (the state of nature) in which might rather than right ultimately decides all irresolvable (reasonable and unreasonable) disputes regarding their shared private lives.

We have seen that Kant's thesis is that only by introducing an inprinciple impartial authority into private care relations can they be made rightful. Only then can private care relations be regulated without reproducing the problems associated with their dependency, asymmetry and particularity. Influenced by Rousseau, Kant argues that only a public authority has the right kind of impartiality: it can represent both parties to a conflict, no other party and yet neither party in particular. The reason is that a public authority represents the general, united will of the interacting persons by establishing itself as a liberal rule of law to regulate private interactions involving coercion. Kant may have been the first to argue that only through a public authority of this kind are the coercive elements of care relations elevated from might into right, thus dismantling the caregiver's castle. And, of course, if it is true that good care relations require a public authority, including a liberal legal framework of related private law, then care cannot be prior to or independent of justice and virtuous private individuals are insufficient to ensure good private care relations. In this case, there is a sense in which rightful care, as enabled by private fiduciary and family law, is prior to and provides the framework within which virtuous care can truly flourish.

\section{Systemic Dependency Relations}

Care theorists' common assumption that good caring relations require only virtuous private individuals is aligned with a prudential conception of justice and the state. Insofar as Kittay affirms a Humean conception of the circumstances of justice (as traditionally understood), she affirms

CAMBRIDGE JOURNALS

http://journals.cambridge.orgownloaded: 12 Oct 2012
VOLUME 17 - 2 KANTIAN REVIEW $\mid \mathbf{3 4 5}$

IP address: 140.192.110.226 
two things: justice is a remedial virtue and the state is the superior instantiation of this remedy (IO8). ${ }^{24}$ The reason is that it is much easier to realize justice through the state, and the state merely does what individuals ought to do, but typically fail to do in the state of nature due to human frailty and limited resources. Whether we are talking of Rawls's own or Kittay's revised principles of justice as fairness, individuals could (in principle) specify, apply and enforce them on their own in the state of nature. It follows that the coercive rights of the state are ultimately understood in terms of the rights individuals have against one another. Consequently, the coercive rights of states (public right) are seen as in principle co-extensive with those of private individuals (private right).

That these assumptions also inform Held's account of justice and the state can be seen by her description of the kind of liberal theory envisioned as complementing her account of care. Our accounts of justice and individual rights should be 'left-wing' in that they should defend the unemployed, marginalized, and poor persons' social and economic rights ( $\mathrm{I}_{7}$ ). Moreover, our theories of justice should be 'feminist' in that the sphere of justice includes public, legal protection of women and children against any violence by husbands and fathers at home (I30, I48) as well as wives' right to (economic) independence from their husbands (I2, I30). Held also emphasizes that justice and care work together to empower the non-autonomous in the ideal society. For example, she argues that the institutions of 'health care, child care, [and] education' should be governed by justice and care (I I 6, cf. 50, $69-70,8 \mathrm{I}, \mathrm{I} 20)$. Importantly, creating such a caring and just society is not a matter of charity $(44,5 \mathrm{I})$, but of respecting care relations, and it justifies a radical, even global restructuring of society. But, still, all these rights of justice are envisioned as individual rights - rights that in turn are complemented by individuals' care.

Unfortunately, it does not seem philosophically sustainable to see systemic rights (public right) as reducible to individual rights in this way. First, it is not clear that individuals can rightfully be seen to enforce Kittay's three principles of justice as fairness. Surely, private individuals cannot have rights to redistribute resources as these principles require. As Robert Nozick famously objects to Rawls in his Anarchy, State, and Utopia (1974), how can a private right to redistribute resources in response to need or lack of means be reconcilable with a liberal notion of private property rights? Second, even if we could solve this problem, it seems that it is in principle impossible for individuals to exercise this

346 KANTIAN REVIEW VOLUME 17 - 2

CMMBRIDGE JOURNALS 
right, since it is impossible for every individual simultaneously to assume the systemic control needed to effect the redistribution. Then again, if there is no account of how all are secured legal access to means, then the account gives up on its 'left-wing' aspirations. To see how similar problems arise in Held's conception, consider the economic dependency relations between employees (dependants) and employers (independents) in the economy. If Held insists that virtuous individuals exercising their rights and duties can interact in the economy in normatively unproblematic ways, then individuals must have related enforceable rights. Yet again, it seems both impossible that all the particular individuals could control employment practices in the economy simultaneously, and if one of them did manage to assume such control, surely she would be subjecting everyone's freedom to her arbitrary choice, which is inconsistent with a respect for freedom. In fact, the problem of economic dependency is not solved even in cases where conflicts happen not to arise. The weaker (unemployed) are still subject to the choices of the stronger (employers), since a radical asymmetry and dependency remain characteristic of the relation. ${ }^{25}$

Third, notice that both Kittay and Held encounter problems matching up particular persons' rights to care with other particular persons' duties to assume caring responsibilities. Kittay argues that a great advantage of the care tradition's relational conception of the self is that it can cover the needs of each (1999: 66). But then Kittay faces the problem of explaining how it is not a matter of chance that everyone ends up with such connections. She sometimes attempts the explanation by saying that everyone is 'a mother's child'. But some people who have given birth to children are, as care theorists often point out, incapable of being parents, and parents die. Appealing to de facto relations therefore will not do - we need an account of how to establish such relations in the right way when they are non-existent. Held, too, fails to match the rights of particular dependants - those, for example, whose incapacitation makes it impossible for them to set and pursue ends of their own - with the duties of particular independents. She does not explain how, say, an abused or abandoned child has enforceable rights against strangers to assume responsibility for her. Moreover, it does not seem right that a person (the stranger) who has done nothing to contribute to the child's tragic situation should be under a legal obligation to adopt it. Yet, if Held cannot explain the legal obligation to abandoned children at the level of private individuals (as her commitment to the view that good caring needs only virtuous private individuals requires her to do), then she fails to match up the rights of

CAMBRIDGE JOURNALS

http://journals.cambridge.orgownloaded: 12 Oct 2012
VOLUME 17 - 2 KANTIAN REVIEW $\mid \mathbf{3 4 7}$

IP address: 140.192.110.226 
particular dependants with the duties of particular others. And if she cannot explain the complementarity of individual rights and duties, then the rights of children and the incapacitated are dependent upon strangers' benevolence or upon arbitrary choices - and these dependants are left fundamentally unprotected.

Held may respond that this objection expresses a fundamental misunderstanding of the role she envisions social connectedness to play in the ideal society. She may argue that the notion of society presupposes that individuals consider themselves connected, and so will establish socio-economic institutions to ensure that everyone is cared for. But if such a feeling of social connectedness is a precondition for the possibility of dependants' rights to care, then their rights are dependent upon the existence of other persons' feelings (of connectedness). Here Held may contend that care theory entails a radical restructuring of the world such that it is a more caring place. The problem with this argument is that unless the right moral emotions and motivation are already present, persons must be coerced to take part in this radical restructuring, and a person who is forced to give her belongings to, or otherwise take care of, others is not in a caring relation as Held conceives it. That is, the caregiver must have both the appropriate (caring) moral emotions and motivations: the action must be done because one cares for the carereceiver. But surely no one can be forced to have such emotions or moral motivations. Hence, either the envisioned radical restructuring of social institutions is in principle coercive, in which it is not the 'caring society' that Held envisions, or it would have to be a voluntary revolution - a revolution we ought, but cannot be coerced, to take part in. And, of course, if it is a voluntary revolution, then it cannot be the solution to the problem of securing the rights of abandoned or abused dependants.

Finally, even if we grant that individuals have the right to enforce justice as fairness or Held's conception of justice, then, as Simmons (2000) argues, we need an additional account of how the state obtains the right to do so on their behalf. If our answer to this last question is simply that it is prudent that the state does it, then we have explained only that it is stupid not to establish a state - not that it is wrong to reject its establishment.

\section{The Solution: A Kantian Revision of Rawls's Conception of Justice and the State}

Fortunately, there are liberal solutions to all the problems identified above. Explaining rightful interference in private care relations is solved

348 KANTIAN REVIEW VOLUME 17 - 2

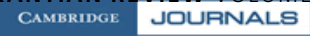


by Kant's account of private right. That account explains why the public authority can interfere in private care relations without thereby intruding, since it represents both parties and yet no one in particular. ${ }^{26}$ Kant's separate account of public right can take care of the remaining worries. Kant's basic claim is that, once the state establishes its monopoly on coercion, it must reconcile this monopoly with each citizen's right to freedom. To accomplish this, it must establish certain public, systemic measures that ensure that all citizens' freedom is subject to public law and not to each other's arbitrary private choices. Moreover, when the state institutes these public right measures, individuals obtain claims on their public institutions that go beyond those issuing from their private rights. In so doing, the state ensures that private dependency relations inconsistent with each citizen's innate right to freedom do not arise. To make a long story short, these public systemic measures are quite similar to Rawls's account of justice as fairness, which according to the analysis presented in this paper should be understood as, fundamentally, an account of public right. Consequently, rather than opting for Kittay's additional principle of (systemic) justice to capture the particularity of private dependency relations, which it cannot do, I suggest liberal accounts will want to stay with Rawls's original two principles and instead supplement Rawls's account with an account of private care right $^{27}$ - much like Kant's account of status right. Thus each person is secured rights to care as a matter of private right, and those involved in care relations are also secured systemic freedom (or independence) as a matter of public right. ${ }^{28}$

My proposal, then, is that Rawls's considered account should not be seen as trying to identify what private society or private persons should do - which opens up the door to all of Nozick's libertarian objections but as an ideal account that emphasizes what a 'public society' or the public authority must do. According to this interpretation, there is a crucial difference between a private conception of social cooperation and a public conception of social cooperation - a difference that is not captured by Kittay's, Nozick's or any similar interpretation of Rawls's position. Moreover, once we incorporate Kant's distinction between private and public right into Rawls's account, a much stronger position ensues. We can then distinguish between: (I) how the state enables rightful private interactions through the public positing, application and enforcement of private law; and (2) how the state enables rightful systemic relations through the positing, application and enforcement of public law. That is, on the one hand, the state will set up public institutions that are themselves governed by public law but whose

CAMBRIDGE JOURNALS

http://journals.cambridge.orgownloaded: 12 Oct 2012
VOLUME 17 - 2 KANTIAN REVIEW $\mid \mathbf{3 4 9}$

IP address: 140.192.110.226 
establishment is constitutive of rightful private relations, including private care relations. For example, through its public institutions, the state posits, applies and enforces private family law regarding things like parents' duties concerning their children's education and healthcare. These public institutions are governed by public law, but their primary aim is enabling rightful private relations, and they should be seen as constituting part of what Rawls calls the 'basic structure'.

On the other hand, the state must ensure that the larger systems within which people exercise their private rights, such as the economy, the financial systems, the educational system and the healthcare system, are reconcilable with each citizen's right to freedom. These systems are coercive in that they set the enforceable parameters within which people exercise their private rights, which is why they must also be governed by public law - and not by private persons or groups of private persons. These institutions constitute another aspect of the basic structure. Since these institutions are fundamentally coercive, as Rawls emphasizes, the challenge is to ensure that the monopoly on coercion, of which they are a part, really is a public monopoly on coercion. To that end the public authority must ensure that all its exercises of coercion, including the entire system of coercive laws, are reconcilable with its role as representative of its citizens as free and equal. ${ }^{29}$ For example, each citizen's freedom and equality is inconsistent with conditions in which poor persons' legal access to means is fundamentally dependent upon rich persons' choices to hire them or to help them with charity. It is also inconsistent with conditions in which wives' legal access to means can be obtained only through their husbands' consent. Furthermore, citizens' freedom and equality is inconsistent with conditions in which the property-determining systems themselves - the economy and the financial systems - are subjected to some particular private persons' choices. Avoiding such systemic injustice is at the core of the state's rights and duties towards its citizens (public right), and they are not matched or reducible to citizens' private rights and duties against one another. ${ }^{3 \circ}$

The upshot of this proposed Kantian revision is that public right is both constitutive of rightful private right and has its own, additional systemic concerns. ${ }^{3 \mathrm{I}}$ Though Kittay's and Rawls's focus on systemic rights is a step forward, I suggest (conformably with Kant's principles) that they should have paid more attention to the difference (and relationship) between public and private right when it comes to care relations. And indeed, had Rawls done so, he (I) would not have had to appeal to

350 KANTIAN REVIEW VOLUME 17 - 2




future citizenship in order to capture the state's obligations towards mentally non-autonomous persons, and (2) would have been able to secure each person a right to care, something Kittay (and others with her) is correctly worried about. Rawls can avoid appealing to future citizens by taking on Kant's conception of 'passive' citizenship. ${ }^{32}$ Passive citizens (dependants) have a right to find themselves in rightful private care relations at all times - a matter of private right. Hence, all children have a claim on the state that they are protected and cared for in their private homes. Moreover, parentless children have a claim on the state that it assumes legal guardianship until new parents are found. In addition, children have stronger claims on their parents than on public institutions with regard to the provision of material resources, since the state's necessary minimal contributions track only poverty. Similarly, although care-receivers' primary claims are against their caregivers, both carereceivers and caregivers have a claim on the state that it provides them safe haven when facing abusive conditions in their families and households. The state cannot force citizens to choose between staying in abusive situations or having no household at all. Furthermore, all citizens, including children, have a right, as a matter of public right, to become, insofar as possible, 'active' citizens in the future. The extent to which a particular state can facilitate this process (i.e. beyond providing the aforementioned minimum provisions) will depend upon the state's actual ability to provide good conditions for its citizens. More affluent states will be able to provide better institutional conditions under which passive citizens are secured legal access to the means, such as student loans and educational opportunities, necessary for working themselves into active citizens who can partake in public deliberations and hold public offices. The full analysis of the state's rights and obligations with regard to non-autonomous persons therefore includes both an account of how public institutions enable rightful private care relations in the present and an account of these persons' continuous and changing claims on public institutions to secure them active citizenship insofar as their capacities and the state's current material conditions allow. ${ }^{33}$

\section{Conclusion}

I have argued that meeting the challenges posed by care theorists to liberal theories of justice requires the distinction between a private right and a public right account of care relations, while recognizing that public right is part of the solution to enforceable private right. Justice demands that care relations are viewed from two different perspectives (private and public right), each with its own kind of lens. From the

CAMBRIDGE JOURNALS

http://journals.cambridge.orgownloaded: 12 Oct 2012
VOLUME 17 - 2 KANTIAN REVIEW $\mid 351$

IP address: 140.192.110.226 
perspective of private right, the focus is on relations between particular caregivers and their care-receivers as well as on public authorities as constitutive of making these private relations rightful. From the perspective of public right, the focus is on how public authorities function as systems of liberal law as well as on how particular care relations function within a just systemic whole. Where the private right lens sees relations as fundamentally bilateral, the public right lens sees them as fundamentally omnilateral. Public right constitutes the systemic lens, whose focus is to ensure that the wrong kinds of private dependency relations do not arise within 'the basic structure', or in the public political, economic and financial systems. Public right also ensures that the public institutional whole is consistent with everyone being able to work towards active citizenship with full participation in public life insofar as her physical and mental capacities and the state's overall material conditions allow. By making our account of care responsive to the concerns of both private and public right, we succeed in capturing many of the concerns with respect to particularity common to much liberal thought and care theorists. But we do so in a way that overcomes those problems as correctly identified by the care theorists, but which currently also characterize their own accounts of care relations.

Email: hvarden@illinois.edu

\section{Notes}

I would like to thank Lucy Allais, Richard E. Acquila, Ann E. Cudd, Rachel Bryant, Deen Chatterjee, Michelle DeMatteis, Marilyn Friedman, Amy Mullin, Peter Niesen, Arthur Ripstein, Anita Superson, Shelley Weinberg, the audiences at the North American Society for Social Philosophy's 24th International Social Philosophy Conference ('Race and Diversity in the Global Context'), at Millersville University, Lancaster, PA, I2-I4 July 2007, and at 'Feminist Legacies/Feminist Futures', Hypatia's 25th Anniversary Conference, University of Washington, 22-4 Oct. 2009. Also, thanks to the audience and my commentator Jonelle DePetro at the Illinois Philosophical Association Annual Conference, Northern Illinois University, 7-8 Nov. 2008, the audience and my commentator Claudia Mills at the second annual Rocky Mountain Ethics Congress, 6-9 Aug. 2009, Boulder, CO, the audiences at the departments of philosophy at the University of Newcastle upon Tyne, the University of St Andrews (Dec. 2008) and the 'New Voices in Legal Theory Roundtable', and two anonymous reviewers at Kantian Review. A special thanks also to Shelley Weinberg for her invaluable comments regarding the presentation of the ideas in this paper.

I Baier (I996: I8-32), Held (2006: I3ff.), Kittay (I999: I-I9, 62-3), and Tronto (2005: 25I-63).

2 For care theorists' agreement with Williams's emphasis on particularity, see Held (2006: IO-I I, 63-4, 92-5, I30, I4O), Tronto (2004: 252-3, 255 ff.) and Kittay (I999: $53-4)$.

3 Cf. Held (2006: IO-I3, 3 I-2, 46, 8I, I4I, I47); Kittay (I999: I3ff., 3I, 38-4I, 49-50, 76-7); Tronto (2004: 252-8).

352 KANTIAN REVIEW VOLUME 17 - 2 CAMBRIDGE JOURNALS 
4 See also Okin (1989).

5 Held 2006: I4-I 5, I 7, 24, 38, 42, 63-4, 68, IOI-2. All unidentified references in this subsection (2.I) refer to Held (2006).

6 Ibid. IO-II, 36, 63-4, 92-5, I30, I40.

7 Examples include ibid. 32-3, 36, 49, 5Iff., 53-4, 99, I 58.

8 Cf. Tronto (2004: 259), Baier (I996: 3 I-2).

9 Held 2006: I4, 7 Iff., 88-9, IOI, I32ff.

I0 Ibid. 24-5, 68, 73, 80-I, 87, I00, IO2, I40-7, I 58 .

I I Cf. ibid. I6-I7, 28, 68-9, Iог.

I 2 Ibid. 22, I32, I38-9. Cf. Tronto (2004: 255-7).

I3 Held 2006: Ioff., 36-9, 42-3, 46, 52, 70ff., 74, I30, I32, I39, I 58

I 4 In the next few paragraphs, my aim is to illustrate what I take to be core insights in Kant's account of private 'status' (or care) rights by applying this part of his theory of justice to critique the care theories. Hence, insofar as Kantians agree with my interpretation of Kant's theory of justice as presented below, I believe they will be sympathetic to the Kantian objections provided in these paragraphs.

I 5 Since Held's analysis is founded on assumptions shared with much liberal thought, it is not surprising that several of the above problems are also recognized by liberal thinkers who have actually tried to give an account of private care relations. For example, the Lockean A. John Simmons sees several of the above problems as inherent in the Lockean conception of children's rights, and they lead him to conclude that the Lockean position cannot make sense of parent-child, or more generally, care relations involving persons incapable of moral responsibility. The heart of the problem, as Simmons sees it, is that since children cannot exercise rights, they cannot be seen as 'having' them in the Lockean sense of the term. The issue of children's rights is therefore a Catch-22 for the Lockean position: it is because they are unable to exercise rights that children need special rights, and yet since they cannot exercise rights they cannot be seen as 'having' such special rights. The solution to the problem of children's rights therefore cannot simply involve an appeal to children's rights without also providing an independent account of the exercise of these rights. See Simmons (2000: I93-200).

I6 Although framed quite differently, Marilyn Friedman (2008) also worries about some of these implications of care's alleged priority to justice.

I7 All unidentified references in this subsection (2.2) refer to Kittay (I999).

I 8 Here and throughout this paper, I refer to Kant's Metaphysics of Morals (Kant I996) by means of the abbreviation $M M$ as well as by means of the Prussian academy pagination.

I9 See Varden (2007) for expansion on this point.

20 The difference between private right and private law and between public right and public law is that 'law' refers to posited law, whereas 'right' refers to the principles specified when positing law. As is evident by now, on the Kantian analysis I am defending, private individuals can specify the principles of private and public right, and they can provisionally specify and apply them in particular situations. Private individuals cannot, however, specify, apply and enforce these principles such that the resulting interactions are conclusively rightful. The state is the means through which the specification and application of principles of right is made conclusively rightful - and so rightly enforceable - namely by transforming principles of private and public right into private and public law by the legislative authority (specified), which is then applied and enforced by the judiciary and executive arms of government. I provide a general interpretation of this aspect of Kant's theory of justice in Varden (2008).

CAMBridge JOURNALS

http://journals.cambridge.orgownloaded: 12 Oct 2012
VOLUME 17 - 2 KANTIAN REVIEW $\mid 353$

IP address: 140.192.110.226 
2 I See n. I9 above.

22 It is uncertain exactly how many persons are domestic workers worldwide, but it is certain that the numbers are at least in the tens of millions (http://www.aclu.org/ womens-rights/trapped-home-global-trafficking-and-exploitation-migrant-domesticworkers\#LinkTarget_666). At the annual International Labour Conference, organized by the International Labour Organization (ILO) in July 20I I, conference delegates adopted the Convention Concerning Decent Work for Domestic Workers (http:// www.ilo.org/ilc/ILCSessions/IoothSession/reports/provisional-records/ WCMS_I $57836 /$ lang-en/index.htm). In light of Kant's analysis above, it is interesting to note that this convention not only secures domestic workers the same rights as other workers, but also aims 'to supplement the general standards with standards specific to domestic workers so as to enable them to enjoy their rights fully' (pp. 2, 4). Like Kant, this treatise emphasizes that normal contracts are insufficient to protect vulnerable domestic workers; special legal protection is needed.

23 I say 'Kantian' here because Kant himself was homophobic; see Varden (2007).

24 All unidentified references in this section refer to Kittay (1999) or Held (2006), as evident from context.

25 Held might object that these problems are exactly why we need welfare rights such as unemployment benefits. Unfortunately, this solution is unavailable to Held, since the conception of welfare rights needed is inconsistent with her assumptions that good caring relations require only virtuous private individuals, and consequently that justice and the state are merely prudential responses to vice (2006: 56). Because Held assumes that all we need for good, caring relations are virtuous individuals who care and exercise their individual rights, her account of the caring society must be conceptually reducible to virtuous, bilateral private relations or interactions. But welfare rights are not rights that hold between private persons, for they are rights held by citizens in relation to their public systems. For example, unemployment rights are rights citizens hold against the state when they cannot obtain employment in the economy. Again, the solution to this problem, I suggest with Kant, is an account justifying the establishment of a public authority with institutional control over the economy. But giving such an argument requires that we give up the notion that justice and the state are merely prudential responses to vice and inconveniences in the state of nature.

26 It would take another paper to explain how the proposed account would be applied to non-ideal situations, including how we should analyse situations in which the public authority does 'intrude' - and hence fails to act as a public authority - and how we should analyse our political obligations in these situations. See also n. 33 on this point.

27 One may, I believe, view this account as a necessary 'spelling out' of what Rawls means by citizens' 'basic liberties' (Rawls r999: 52) or 'basic rights and liberties' (Rawls I996: 5) in his first principle of justice as fairness.

28 Arthur Ripstein (2006) is, I believe, sympathetic to such a reading.

29 Kant puts this point in terms of citizens' right to freedom, equality and independence (see $M M$ 6: 3I4). For reasons of simplicity of exposition, use Rawls's language of freedom and equality here. I am truer to Kant's own language in Varden (2006, 2010).

30 One might object by saying that it is a 'cold' way of providing care. I do not think so. Many care and other left-wing theorists look to the Scandinavian states for inspiration when it comes to providing good care. What distinguishes them from other countries, however, is not an excess of particularly virtuous people, but the presence of public institutions to which each citizen is given claims. For example, in Norway every citizen has a right to welfare (a home, including food, heat and

354 KANTIAN REVIEW VOLUME 17 - 2

CAMBRIDGE JOURNALS

http://journals.cambridge.orgownloaded: 12 Oct 2012

IP address: 140.192.110.226 
clothing), to healthcare and to education through the equivalent of high school and to full tuition for any higher education through the completion of a master's degree. Every citizen is also guaranteed student stipends and loans to cover the cost of minimal living expenses while pursing higher education. Consequently, a person's possibility of a decent home, education and health is not subject to another private person's arbitrary choices, such as the parents' willingness or ability to pay for education or, if this is lacking, another person's private charity. These are public systemic solutions to systemic problems - they are not responses to vice as such.

3 I Incorporating these revisions would, I believe enable Rawls to overcome all the objections Martha C. Nussbaum (2000) raises in her careful critique of Rawls's ability to deal with care relations.

32 For my interpretation of Kant's account of systemic justice, see Varden (2006, 2010).

33 One could object that even if we accept the Kantian ideal as better at identifying what we aim to accomplish, it does no good in non-ideal conditions where the public institutions, including the legal system, are inadequate. Responding to all the circumstances of nonideal theory would take me far beyond the scope of this paper. Still, do note that the same objection holds against any ideal theory: care theories as well as the Kantian theory. The entire discussion above is undertaken in terms of ideal theory. For example, care theorists do not argue that virtue will have to do when our legal systems are sufficiently dysfunctional - a claim Kantians might accept (that provisional justice is as good as it gets under certain conditions). Second, note that identifying the ideal - or clearly demarcating what we are trying to achieve - is still useful even if actual systems of justice are imperfect. Third, once we have identified what can tear down the mighty castle, then we can apply the ideal principles to non-ideal circumstances. But first we must get the principles right.

\section{References}

Baier, Annette C. (1995) 'The Need for More than Justice'. In Moral Prejudices: Essays on Ethics. Cambridge, MA: Harvard University Press, pp. I8-32.

Clement, Grace (1996) Care, Autonomy, and Justice. Boulder, CO: Westview Press.

Friedman, Marilyn (2008) 'Care Ethics and Moral Theory' [review of Held 2006]. Philosophy and Phenomenological Research, 77/2, 539-55.

Held, Virginia (2006) The Ethics of Care: Personal, Political, and Global. New York: Oxford University Press.

Kant, Immanuel (1996) The Metaphysics of Morals. Trans. and ed. Mary Gregor. Cambridge: Cambridge University Press.

Kittay, Eva F. (1999) Love's Labour: Essays on Women, Equality, and Dependency. New York: Routledge.

Nozick, Robert (1974) Anarchy, State and Utopia. New York: Basic Books.

Nussbaum, Martha C. (2000) Women and Human Development: The Capabilities Approach. New York: Cambridge University Press.

Okin, Susan M. (1989) Justice, Gender, and the Family. New York: Basic Books.

Rawls, John (I996) Political Liberalism. New York: Columbia University Press.

- (1999) A Theory of Justice. Rev. edn. Cambridge, MA: Harvard University Press.

- (200I) 'The Idea of Public Reason Revisited'. In Samuel Freeman (ed.), Collected Papers (Cambridge, MA: Harvard University Press), pp. 573-6I 5.

Ripstein, Arthur (2006) 'Private Order and Public Justice: Kant and Rawls'. Virginia Law Review, 92, I39I-438.

Simmons, A. John (2000) Justification and Legitimacy: Essays on Rights and Obligations. New York: Cambridge University Press.

CAMBRIDGE JOURNALS

http://journals.cambridge.orgownloaded: 12 Oct 2012
VOLUME 17 - 2 KANTIAN REVIEW $\mid 355$

IP address: 140.192.110.226 
HELGA VARDEN

Tronto, Joan (2005) 'An Ethic of Care'. In Ann E. Cudd and Robin O. Andreasen (eds), Feminist Theory: A Philosophical Anthology (Malden, MA: Blackwell Publishing), pp. 25 I-63.

Varden, Helga (2006) 'Kant and Dependency Relations: Kant on the State's Right to Redistribute Resource to Protect the Rights of Dependents'. Dialogue: Canadian Philosophical Review, 45, 257-84.

- (2007) 'A Kantian Conception of Rightful Sexual Relations: Sex, (Gay) Marriage and Prostitution'. Social Philosophy Today, 22, 199-218.

- (2008) 'Kant's Non-Voluntarist Conception of Political Obligations: Why Justice is Impossible in the State of Nature'. Kantian Review, I3/2, I-45.

- (20I0) 'Kant's Non-Absolutist Conception of Political Legitimacy: How Public Right "Concludes" Private Right in "The Doctrine of Right". Kant-Studien, 3, 33 I-5I.

Williams, Bernard (I976) 'Character and Morality'. In A. O. Rorty (ed.), The Identities of Persons (Berkeley and Los Angeles: University of California Press), pp. I97-216.

356 KANTIAN REVIEW VOLUME $17-2$ 